Scientific Council for Africa South of the Sahara (1957). Stored Food Products. C.C.T.A. Publ. no. 31 . London: C.C.T.A.

United Nations: Department of Economic Affairs (1950). Agricultural Requisites in Latin America. Report of the Joint ECLA/FAO Working Party, Lake Success, New York. U.N. Publ. Sales no. I950 II.G.I. New York: United Nations.

\title{
Disease losses in potatoes
}

By E. C. Large, Plant Pathology Laboratory, Ministry of Agriculture, Fisheries and Food, Harpenden, Herts

The diseases of potatoes in Britain (for which see Beaumont, I959; McKay, I955; Moore, I959; Whitehead, McIntosh \& Findlay, 1953), are of three main kinds: fungus and bacterial diseases caused by parasitic organisms; virus diseases which, as Bawden (1959) puts it, are aberrations in the nucleoprotein metabolism of the growing plants; and nutritional diseases caused by deficiencies of major and minor elements needed for plant growth. In the consideration of losses it is convenient to take these three types of disease in reverse order.

\section{Deficiency diseases}

Potato crops suffer here and there, and fairly frequently on limestone soils, from deficiency of potash. This disorder, which is all too easily mistaken for potato blight, is manifested by a marginal scorching of the leaves, often followed by collapse of the stems and premature death of the plants (Large, Blenkinsop \& Le Riche, 1946). The consequence is a reduction in yield, and sometimes a predisposition of the tubers, in association with bruising and other factors, to darken on cooking. Less common, among the deficiency disorders, is manganese deficiency, causing premature yellowing of the foliage and reduction of yield, particularly on fen soils. Deficiencies of other trace elements also occur. No estimate is possible of the losses caused by these troubles, but they exist, and the attention they receive from the soil chemists contributes to the gradual rise in the level of our potato yields over a long-term period.

\section{Virus diseases}

The two principal virus diseases of potatoes, leaf roll and rugose mosaic (virus $Y$ ), are spread by aphids. In the course of their feeding these insects take sap from the diseased plants and inject it into healthly ones. The sap contains products of the disordered nuclei in the plant cells, and these products derange more nuclei in the plants injected, causing not only a partial breakdown in the normal genetic functioning of the plant, but also the production of more virus by a kind of chain reaction, which spreads from the point of injection into other parts of the plant. Externally the diseases are manifested by various mottlings, crimpings and rolling of the leaves, followed by a general reduction in the whole vigour of growth. The viruses go down into the tubers and if these are planted for seed an enfeebled crop is produced in the following year. As the viruses spread to more and more plants in a potato stock it is said to 'run out' or degenerate. The virus diseases affect the growing plants and 
cause reduction in the yield of potatoes; they do not cause rotting of the tubers either in the ground or in the store.

Because of the potato virus diseases farmers in England and Wales have, in general, to obtain 'new' seed from Scotland or Ireland every other year. This control measure is effective, but it increases the cost of production. In round figures (Broadbent, Burt \& Nix, I957) where new (A Certificate) seed from Scotland costs $£_{24} /$ ton, the small ware that would otherwise be planted for seed is worth about $f_{0} 12 /$ ton as ware. Planting new seed every other year instead of saved seed every year therefore costs about $f^{6}$ per acre, which for half a million acres of potatoes comes to about $£ 3$ million per annum. This expenditure is on a crop worth at least $£ 40$ million, and it is not all loss. It gives Scotland and Ireland a valuable cash crop much needed in their economies; it leaves the production of seed in expert hands; and it results in the utilization of the potato land in Britain to the best advantage. The seed-growing areas of Scotland and Ireland are relatively free from aphids, so that with good care of the seed stocks, roguing out of infected plants, and stringent field inspection, seed potatoes can be produced of very high quality in respect of freedom from virus diseases.

\section{Potato blight}

The principal fungus disease of potatoes in Britain is potato blight, caused by the phycomycete, Phytophthora infestans. This disease reduces the total yield of potatoes by killing the foliage before a full crop of tubers has been produced; and it may also infect the tubers, causing them to rot in the ground or in store. Although the disease has been in our potato crops since 1845 , and in this century there has been a great expense of material and labour in potato spraying, it is only in the past decade that a realistic estimate of our national blight losses (in England and Wales) has been obtained. Potato blight is very dependent on weather conditions and its incidence varies greatly from year to year and from district to district. Some potato varieties are also more susceptible than others. Since $195^{\circ}$, when a disease-measurement section was set up at the Plant Pathology Laboratory, Harpenden, surveys have been carried out by the National Agricultural Advisory Service in all parts of the country each year to ascertain (inter alia) the date at which the growth of maincrop potatoes is stopped by blight (Large, I 958). By many spraying trials, and periodic liftings to determine the course of tuber development, it has been found that, in England and Wales, and in maincrops, the relationship between loss of potential yield and date of stoppage of growth by blight is generally as follows:

$\begin{array}{ccccc}\text { End of } & \text { Mid- } & \text { End of } & \text { Mid- } & \text { End of } \\ \text { July } & \text { August } & \text { August } & \text { September } & \text { September } \\ 50 \% & 28 \% & 13 \% & 4 \% & \text { None }\end{array}$

It thus becomes possible to interpret the country-wide field observations obtained each year, by means of maps showing the date of stoppage of growth by blight in the various regions. Two such maps, for unsprayed Majestic (the predominant 
maincrop variety), are shown in Fig. I. The map on the left is for 1958 (one of the worst blight years in living memory) and the other is for 1959 , which had a very fine summer, with the incidence of blight at a minimum.
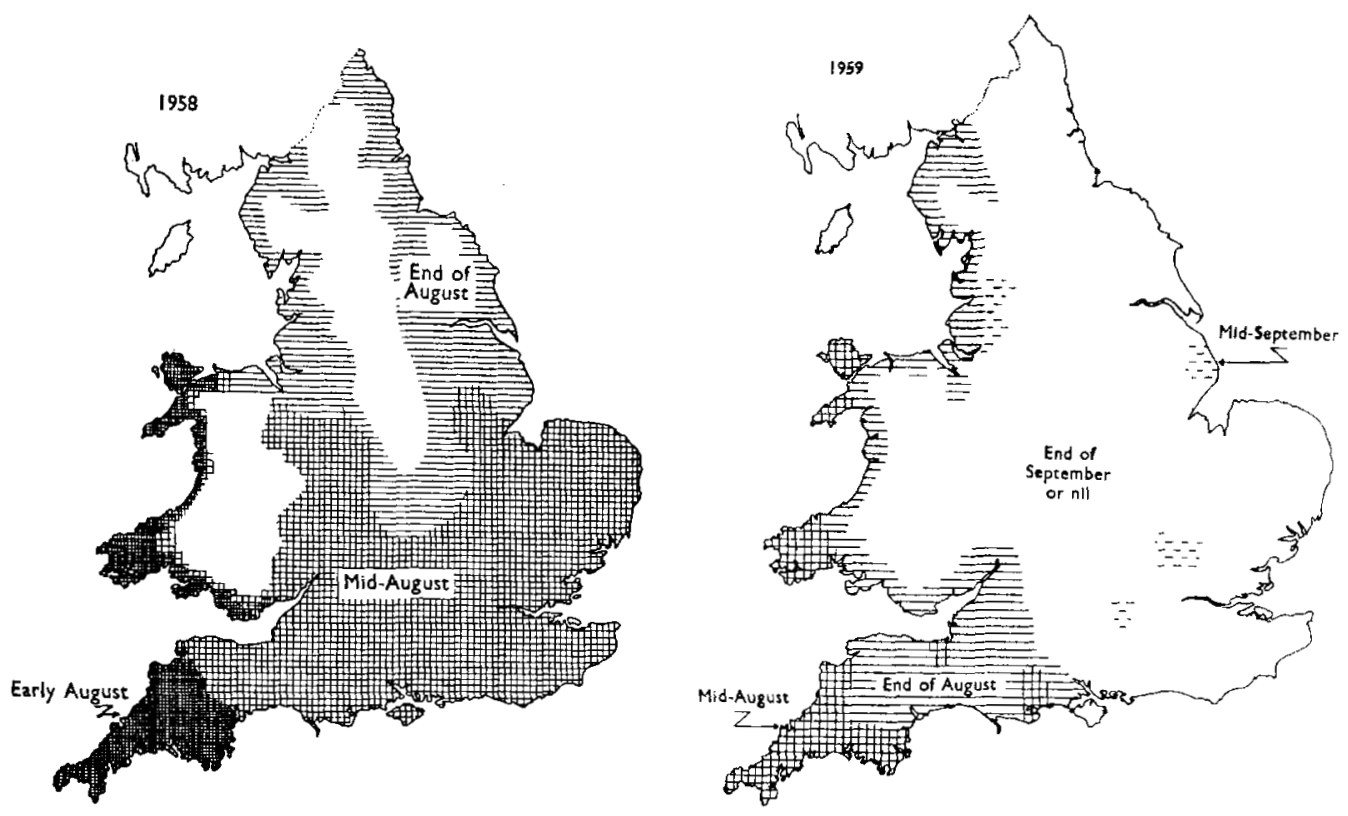

Fig. r. Dates of stoppage of growth by blight in unsprayed Majestic potatoes, 1958 and 1959 .

Over the ro-year period $(1947-56)$ it was found that blight epidemics killing the potato haulm by the end of August, and therefore causing substantial loss, occurred in ro years out of ro in the South-west; 6 years out of Io in the Fens; 5 years out of Io in the rest of the south of the country; and in o years out of Io in the North.

These figures refer to the unsprayed crops; in estimates of the national loss it is necessary to take into account the effect of the amount of protective spraying that is done. Such spraying hardly ever keeps the haulm entirely free from blight in a 'blight year'. In general, good commercial spraying defers the stoppage of growth by blight by about a fortnight. If there were no injurious side-effects of spraying this would mean that where the blight kills the haulm of unsprayed crops by midAugust causing $28 \%$ loss it will not kill those of the sprayed crops until the end of August, so that the loss is reduced to $13 \%$. In fact ground spraying or dusting inevitably causes some wheel-damage (cutting and crushing of the sprawling stems in the rows between which the sprayer wheels have to pass), and in hot dry seasons there may also be some loss (not usually very great) due to phytotoxic effects where copper sprays are used. Corrected for these incidental losses, the average effect of good commercial spraying is to save $14 \%, 8 \%$ or $\mathrm{I} \%$ of the potential crop, where the epidemic stops growth in the unsprayed by mid-August, the end of August, or $20(1) 3$ 
mid-September, respectively. Where blight does not stop growth in the unsprayed until the end of September or later, there may be a loss from spraying of from 3 to $6 \%$ of the potential crop.

The potential crop, which is to say the crop that would be produced if there were no blight, varies according to the rainfall during the growing period, being in general highest in years when there is abundant (but not excessive) rain, and lowest in the dry seasons when there is little blight but the crop suffers from drought. Hence the actual yield is often highest in the 'blight-years' despite the heavy toll taken by blight. This is one of the most significant points brought out by our surveys in England and Wales; and in a study of blight epidemics throughout the world (Cox \& Large, 1960) it was also found to apply, very generally, in all the principal potato-growing regions.

The amount of blight in the tubers is not directly related to that on the foliage; it depends chiefly on the variety, being much greater for example in King Edward than in Majestic; and it also depends on the amount of soil cover over the potatoes in the rows. Even in a blight-year more than half of our crops suffer little or no loss from blight in the tubers (Large, 1958), but there are always a few crops in which the loss is heavy. In most years the mean national loss from blight in tubers in England and Wales is about $3 \%$ of the potential yield; though in the very dry years such as 1959 it may fall to about $\mathrm{I} \%$.

Taking into account all the important factors, including the variation of potential crop with the rainfall, the areas under potatoes in the different districts, the amount of spraying done, and the loss from blight in tubers, my estimates of the effect of potato blight on the maincrop yields in England and Wales over the ro-year period 1947-56, and in the two exceptional years $195^{8}$ and 1959 , are as shown in Table 1.

Table I. Analysis of the effect of potato blight on maincrop potato yields in England and Wales (tons/acre)

\begin{tabular}{|c|c|c|c|c|c|}
\hline \multirow[b]{2}{*}{ Potential yield } & \multicolumn{3}{|c|}{$1947^{-5^{6}}$} & & \\
\hline & $\begin{array}{c}\text { Blight } \\
\text { years* } \\
9.6\end{array}$ & $\begin{array}{c}\text { Other } \\
\text { years } \\
7.7\end{array}$ & $\begin{array}{c}\text { Io-year } \\
\text { mean } \\
8.6\end{array}$ & $\begin{array}{c}1958 \\
8 \cdot 4\end{array}$ & $\begin{array}{c}1959 \\
8.8\end{array}$ \\
\hline $\begin{array}{l}\text { Defoliation loss by blight if all crops } \\
\text { were left unsprayed }\end{array}$ & $x \cdot 6$ & $0 \cdot 2$ & 0.8 & $2 \cdot I$ & $0 \cdot x$ \\
\hline $\begin{array}{l}\text { Reduction of defoliation loss by spray- } \\
\text { ing donet }\end{array}$ & 0.3 & -0.1 & O. I & 0.6 & -0.05 \\
\hline Loss from blight in tubers & 0.3 & 0.3 & 0.3 & 0.3 & $0 \cdot 1$ \\
\hline Actual yield of sound ware tubers & $8 \cdot 0$ & $7 \cdot 1$ & $7 \cdot 6$ & $6 \cdot 6$ & $8 \cdot 55$ \\
\hline
\end{tabular}

In $195^{8}$ heavy losses from blight coincided with a potential yield that was low for a wet season, owing to poor growing conditions in the spring and much waterlogging 
in June (Large, 1959); in 1959 the potential yield was exceptionally high for a dry season, owing to some downpours in July. Whatever the figures for the 'freak' years I $95^{8}$ and 1959 may appear to show to the contrary, over the Io-year period $1947-56$, blight had a stabilizing effect on potato yields in this country, as it caused little loss in the dry years when the potatoes suffered from lack of rain, and considerable loss in the blight years when they had plenty of rain.

\section{Common scab}

The other major fungus disease of potatoes in this country is common scab, caused by the soil fungus, Streptomyces scabies. Common scab does not cause reduction of yield or rotting in store, but it is responsible for disfigurement or blemish of the produce, and for some waste in cooking owing to the need for deep peeling to remove the scabbed skin. In collaboration with the Potato Marketing Board we have been studying the incidence of common scab in Great Britain, year by year since 1952, in surveys of some 2500 crops each year (Large \& Honey, 1955).

We have found that in a remarkable number of ways common scab is the direct opposite of potato blight. Its incidence is much greater in dry seasons than in wet seasons; it is more prevalent in the north and midland areas of England than in the Fens or in the south, and it is worse on Majestic than on King Edward.

A few scab spots on a potato are a very trifling defect, except perhaps where extra fancy tubers are desired for prepacking. We have found a consensus of opinion that only when a potato has one-quarter or more of its surface area covered by scab lesions can it be regarded as badly scabbed and objectionable to the consumer. The surveys have shown that the proportion of such badly scabbed tubers in the total maincrop potato yield of England and Wales since $195^{2}$ has been as shown in Table 2. To provide some indication of the way in which the amount of common scab varies with the rainfall during the growing period, figures are given in this table for the total rainfall during the months of June, July and August each year, at York, which is in the centre of one of the worst scab areas in the country-the sand land of east Yorkshire.

Table 2. Percentage of badly scabbed tubers in the total maincrop potato yield of England and Wales, 1952-9, in relation to rainfall during the growing period

\begin{tabular}{|c|c|c|c|c|c|c|c|}
\hline & 1952 & 1953 & 1954 & I955 & 1956 & I957 & 1958 \\
\hline $\begin{array}{l}\text { ercentage of badly scabbed } \\
\text { tubers }\end{array}$ & 4 & 3 & $\mathbf{I}$ & 5 & I & I & - \\
\hline$\therefore$ June-August at & $5 \cdot I$ & 5.9 & $11^{\cdot 2}$ & $4^{\circ} 0$ & $12 \cdot 2$ & 10.4 & $8 \cdot 4$ \\
\hline
\end{tabular}

York (in.)

There is at present no really effective control measure for common scab; although the results of our surveys indicate that on the sand, gravel and alkaline-marl soils, where its incidence is high in dry seasons, irrigation would help to reduce scab as well as to increase the crop.

The economic loss caused by scab in the potato industry varies according to the abundance or shortage of potato supplies. When potatoes are in good demand crops containing even $50 \%$ of badly scabbed tubers may be acceptable on the ware 
market; when there is a surplus, and buyers can afford to be particular, they may reject crops with $20 \%$ of such tubers, or even less. Such rejected crops then have to go for stock feed at $£_{3}$ or $£_{4} /$ ton-thereby fetching less than a third of the ware price.

After even this brief review of the losses caused by the three principal diseases of potatoes in this country, one cannot escape the reflection that lack of rain is more often responsible for shortages of potatoes in these days than all the potato diseases put together. When the soil moisture is deficient the potential yield is low, common scab is worst, the potato spraying that is done against blight is almost entirely wasted and, incidentally, the aphids that spread the principal potato virus diseases are most abundant.

\section{REFERENCES}

Bawden, F. C. (1959). Proc. R. Soc. B, 131, 57.

Beaumont, A. (1959). In Diseases of Farm Crops. London: Collingridge.

Broadbent, L., Burt, P. E. \& Nix, J. S. (1957). N.A.A.S. Quart. Rev. 38, 444.

Cox, A. E. \& Large, E. C. (1960). Agric. Indbk no. I74. Washington: United States Department of Agriculture.

Large, E. C. (1958). Plant Path. 7, 39.

Large, E. C. (1959). Agriculture, 65, 603.

Large, E. C., Blenkinsop, A. \& Le Riche, H. H. (1946). Agriculture, 53, 2 I r.

Large, E. C. \& Honey, J. K. (r955). Plant Path. 4, I.

McKay, R. (1955). Potato Diseases. Dublin: At the Sign of the Three Candles.

Moore, W. C. (1959). British Parasitic Fungi. Cambridge: University Press.

Whitehead, T., McIntosh, T. P. \& Findlay, W. M. (1953). The Potato in Health and Disease. Edinburgh: Oliver \& Boyd.

\section{Food losses through animal disease}

\section{By F. B. LEECH, Rothamsted Experimental Station, Harpenden, Herts}

The principal sources of food derived from the farm stock of the United Kingdom (Table I) are milk and cattle meat. Although sheep are three times as numerous as pigs, they produce only one-third as much food. Poultry, because of their egg production, are about equal in importance to pigs.

Table x. Approximate amount of food (thousands of tons) produced in a year by the four main species of farm stock in the United Kingdom

$\begin{array}{lrcccr}\text { Species } & \text { Meat } & \text { Offal } & \text { Milk } & \text { Eggs } & \text { Total } \\ \text { Cattle } & 820 & 70 & 2570^{*} & - & 3460 \\ \text { Sheep } & 200 & \text { I } & - & - & 2 \text { 7 } \\ \text { Pigs } & 590 & 50 & - & - & 640^{\circ} \\ \text { Poultry } & 210 & - & - & 560 & 77^{\circ}\end{array}$

Animal diseases affect this food supply by causing mortality among the farm stock, by making the food unpalatable (tough or tainted) or unsafe for human consumption, by reducing the efficiency of food conversion and also by reducing the per capita output, for example by causing loss of appetite. They also cause indirect loss through the cost of rearing replacements for the casualties. 